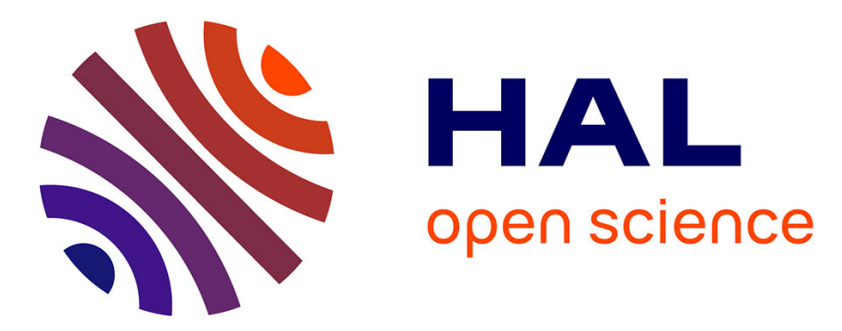

\title{
Towards a Greener Pharmacy by More Eco Design Michel Baron
}

\section{To cite this version:}

Michel Baron. Towards a Greener Pharmacy by More Eco Design: Review. Waste and Biomass Valorization, 2012, 3 (4, SI), p. 395-407. 10.1007/s12649-012-9146-2 . hal-01631587

\section{HAL Id: hal-01631587 https://hal.science/hal-01631587}

Submitted on 30 Nov 2017

HAL is a multi-disciplinary open access archive for the deposit and dissemination of scientific research documents, whether they are published or not. The documents may come from teaching and research institutions in France or abroad, or from public or private research centers.
L'archive ouverte pluridisciplinaire HAL, est destinée au dépôt et à la diffusion de documents scientifiques de niveau recherche, publiés ou non, émanant des établissements d'enseignement et de recherche français ou étrangers, des laboratoires publics ou privés.

\section{(이) $\$$}

Distributed under a Creative Commons Attribution - NonCommercial - NoDerivatives| 4.0 


\title{
Towards a Greener Pharmacy by More Eco Design
}

\author{
Michel Baron
}

\begin{abstract}
This review proposes an overview of the main trends explored by the pharmaceutical industry in order to develop a greener and smarter pharmacy minimizing any negative impact to the environment, and using more sus tainable processes and drugs. If many drugs have their origin in nature, many active ingredients are "toxic by design". Some trials were carried out to design "green pills", or greener active ingredients "benign by design", avoiding the environmental pollution risk. More efforts were developed to reduce fine chemicals production foot prints, and to decrease their E factor. Biotechnology, and the use of enzymes for some transformation reactions is another good way of progress. Advanced galenics allows to reduce drug footprints on environment, since it can deliver the right dose of drug at the right time and at the right place, decrease the drug doses, and lower the wastes. Use of continuous processes is a strong trend in the area of primary and secondary pharmaceutical production. It is linked to the quality by design concept and to the in pro cess control by process analytical technology tools. Added to their diversification strategy, and despite their lower research productivity, and that more and more patented blockbusters become or will become generics soon, it will help the pharmaceutical companies to continue their development. At the same time, these efforts toward a greener pharmacy, and a social education of patients, will contribute to the health organization economies and to preserve the future of our planet.
\end{abstract}

\section{Baron (ه)}

Université de Toulouse, Mines Albi, CNRS UMR 5302, Centre Rapsodee, Campus Jarlard, 81013 Albi Cedex 09, France e mail: michel.baron@mines albi.fr
Keywords Green pharmacy - Benign by design Advanced galenics - Green manufacturing - Solvent free synthesis - Continuous process

\section{Introduction}

The traditional model of pharmaceutical industry has changed a great deal since many factors decreased its profitability: the research productivity lowers, the require ments of health authorities in terms of patient safety are strengthned, the drugs refundings decreases, the block busters patents get in the public domain... As a result, the pharmaceutical industry is searching for new growth drivers. The big pharma companies developed a diversifi cation strategy for 10 years, and the return on investment begins to appear, thanks to the fast growing emerging markets as well. Two main tendencies emerge from this: The development of generics, drugs already in the public domain, with very active international actors (but in this case, the price of drugs is rather low, and cost effective processes are needed for their production), and the devel opment of bio drugs, more adapted to each patient (but in this case, the developing cost is very high, with an uncer tain return on investment). One important new trend con sists in developing a smarter green pharmacy fitting with mankind ambitions on the planet. This must be a global approach, including more eco design for pharmaceutical products and processes.

\section{The Green Pill Paradigm}

If many pharmaceutical drugs come originally from nature, these drugs and their derivatives designed to improve their 
therapeutic action are "toxic by design", and their toxicity depends on the dose used. If they are not destroyed in the metabolism, after emission in the waste water, some remain for a quite long time in the environment. One possibility to avoid this situation is to imagine drugs "benign by design", with a similar therapeutic activity, but a better degradability in the environment.

\section{Drugs from Green Sources}

Many drugs have their origin in nature, and many plants were the basis of traditional medecine for thousands of years, all over the world, in Africa, America, Oceania, India, Asia, Europe [1]. Some examples of products extracted from plants are for instance cardiotonic heteros ids like digitalin, coming from the plant digitalis purpurea, or alkaloids as morphine coming from papaver somniferum (Fig. 1) [2].

The chemists often use a natural molecule as a model to create a therapeutic class using semi synthesis. This sometimes gives more active products, and many alcaloid derivatives have been found active as antitumor com pounds. Some examples are Taxotere, Vinorelbine, or Taxol (Fig. 2) [3].

Bacteria also provides sources of natural products, as for instance antibiotics. When Fleming discovered the anti bacterial action of penicillium's cultures [4], he has already imagined that penicillin was a chemical compound with a
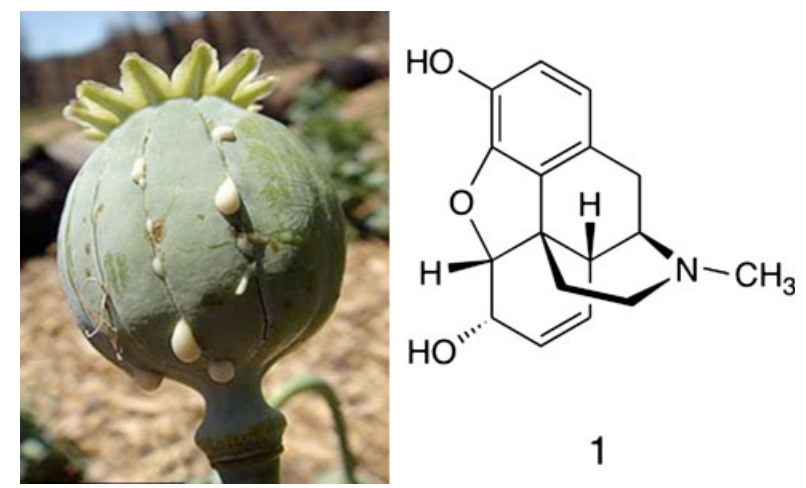

Fig. 1 Papaver somniferum and morphine 1

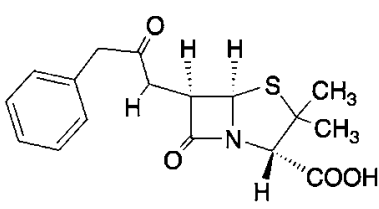

$3 a$

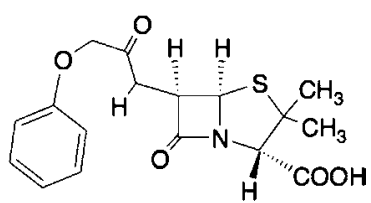

$3 b$
Fig. 3 Penicillin G (a) and V (b)

definite structure. The antibacterial action was actually due to the structure of penicillin G (Fig. 3). This molecule is very interesting and has been widely used for many years. But its major drawback is its sensitivity to acid conditions in stomach, and it cannot be taken orally. Another molecule was developed on account of this, penicillin V (Fig. 3) showing a very similar structure and which can be taken orally, since its $\beta$ lactam ring is stronger for sterical rea sons. This was a great progress and penicillin $\mathrm{V}$ is still widely used for pediatric and other applications. From that time, many antibiotics where developed in various series (cephalosporins, etc.). Biological resources of the oceans have been exploited as well since human history, by catching fish and harvesting algae, and research during last decades on marine animals and algae revealed the impor tance of these resources to produce various molecules as antitumor agents, for the treatment of human deseases [5].

\section{Toxic by Design}

Many natural products display high toxicity, as snake venoms, or natural alkaloids (strychnine,...) synthesized in cells secondary metabolism. Some molecules coming from the nature or their derivatives obtained by semi synthesis are often very active as drugs, and naturally "toxic by design", depending on the dose, and as edicted in Latin by Paracelsus: "dosis sola facit venenum", meaning "only the (inappropriatly high) dose determines that a drug is a poison" [6]. This is the basis of the therapeutic index concept, giving the ratio between the active dose and the toxic dose for a drug.

Semi synthesis is often used to improve drugs action, as in the case of many semi synthetic antibiotics like peni cillin V (Fig. 3), or to create more active artificial drugs

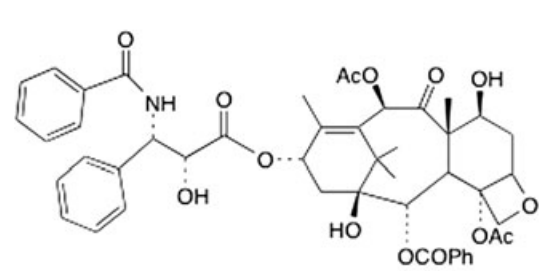

$2 \mathrm{a}$

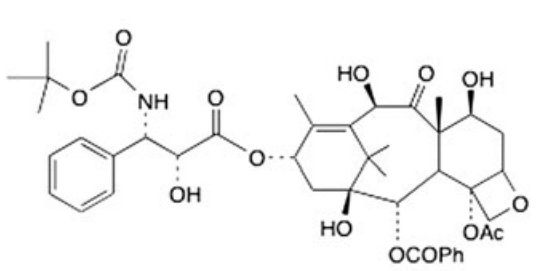

$2 b$

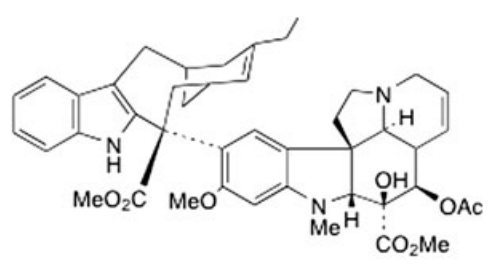

2c

Fig. 2 Semi synthetic antimitotic agents: Taxol (a), Taxotère (b) and Vinorelbine (c) (after Potier [3]) 
Fig. 4 Naproxen (a), its metabolite $6 \mathrm{O}$ desmethylnaproxen (b), and some of their possible glycuronoderivatives (c g) (after Vree [8])<smiles>COc1ccc2cc(C(C)C(=O)O)ccc2c1</smiles>

$4 a$<smiles>COc1ccc2cc([C@H](C)C(=O)OC3OC(C(=O)O)C(O)C(O)C3O)ccc2c1</smiles>

$4 c$<smiles>COc1ccc2cc([C@H](C)C(=O)OC3C(O)C(O)C(O)C3C(=O)O)ccc2c1</smiles>

$4 e$<smiles>CC(C(=O)O)c1ccc2cc(O)ccc2c1</smiles>

40<smiles>CC(C(=O)O)c1ccc2cc(OC3OC4(C(=O)O)OC3C(O)C(O)C4O)ccc2c1</smiles><smiles>C[C@H](C(=O)O)c1ccc2cc(O)ccc2c1</smiles>

41<smiles>C[C@H](C(=O)O)c1ccc2cc(O)ccc2c1</smiles>

49

(as in the case of antitumoral vinorelbine, Fig. 2). Un fortunatly, increasing drug activity can decrease its bio degradability, not only inside the body, but also outside.

Drug Metabolism in the Body

After administration to the patient in a specific dosage form, the drug molecules are absorbed into the circulatory system, and can undergo a broad range of reactions during metabolism. If some drugs can be excreted unchanged by the kidneys, as the antibiotics benzylpenicillin or vanco mycin, most of them are metabolized by enzymes to dif ferent compounds. Drugs are generally hydrophobic, and their transformations lead to more hydrophilic products, easier to eliminate in urine or bile. Drug metabolism oc curing mainly in the liver [7], is divided into two phases:

- Phase I: the functionalization reactions, introducing or unmasking a functional group (including oxydation, hydrolysis, reduction, hydration...). It involves Cyto chrome P 450, a family of enzymes catalyzing various reactions as hydroxylation or epoxydation of different substrates.

- Phase II: the conjugation reactions, leading to highly polar inactive or less active molecules ready to be excreted. The conjugation can be a glycuronidation, a sulfation, acetylation..

In general, the metabolism of a drug decreases its therapeutic effect. This is important, to avoid that after reaching the site of action, the drug produces its effect longer than to be desired or becomes toxic.

An example of metabolism is given in the case of the antiinflammatory drug naproxen (Fig. 4): the original drug is oxidized in humans to $6 O$ desmethylnaproxen (phase I) and both parent drug and metabolite are conjugated (phase II) as acylglycuronides [8].

\section{The Flow of Drugs to the Environment}

After its flow through the body, half the drug is sometimes rejected without change, and remains days, months or years in the water (Fig. 5) [9]. Fortunatly, pharmaceutical prod ucts (active ingredients and metabolites) concentration in the environment is very low, and very far from the thera peutic dose. These substances are not eliminated from the water by usual methods, and a small quantity can be detected even in drinking water. According to the research in this field which began about 15 years ago, the risk of adverse effects through the ingestion of pharmaceuticals 


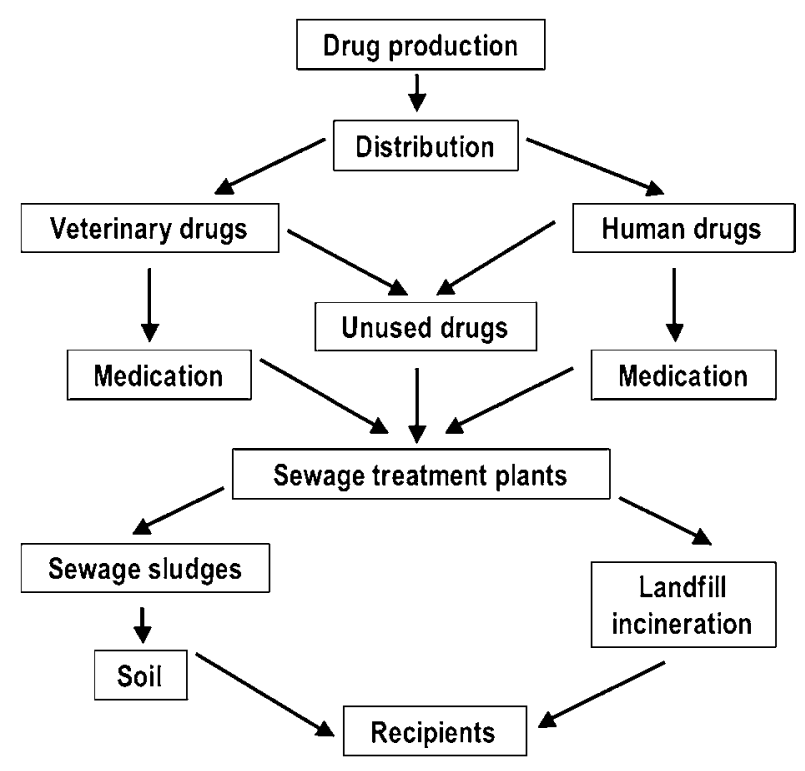

Fig. 5 The flow of drugs to the environment (adapted from [9])

present in the drinking water seems to be negligible [10]. But some researchers are now wondering whether low doses of drugs mixtures could have some consequences for human health. In the case of "chemical mixtures" [11] synergy can exist with other emerging organic contami nants (EOC) and endocrine disruptive compounds (EDC), including oestrogens or bisphenol A (BPA) [12, 13]. These molecules and other coming from phytosanitary products (insecticides, herbicides,...), paints, solvents..., as DDT, PCB or flame retardants are widely spread in the nature, and due to their lipophilic character, they can concentrate in the food chain, with a potential risk for human, but this is still not well established and remains to be investigated [14]. Some smart processes were developed to destroy these compounds in a solid state and are now well estab lished [15, 16]. The treatment [17] and valorization of sediments is also possible [18]. The possibilities of envi ronmental remediation by genetically engineered bacteria was also explored [19].

Anyhow, the diffusion of these molecules in the aqueous environment makes more difficult the waste treatment. Biodegradation of phytosanitary products in biological wastewater treatment was tested successfully [20].

In the case of pharmaceutical molecules, advanced effluent treatment is not sustainable because of energy consumption, efficiency and efficacy, and its appropriat ness must be assessed at a case by case study [21]. It can apply in the case of the pharmaceutical factories industrial effluents, since the wastes are well characterized in terms of quantity and quality. Till now, little is known about the fate of pharmaceutical molecules during sewage treatment
[22], depending on the operating conditions (aerobic, anaerobic,...$)$ as well as in the environment. For instance, a UV desinfection can create new products sometimes more toxic than the initial molecule [22]. Photoproducts can even be formed by natural sunlight. Microbial transfor mations can also create more toxic metabolites, as for instance in the case of BPA, methylated by mycobacterium species to mono and dimethyl derivatives showing increased toxicity on zebrafish embryo exposed to these molecules [23]. Further environmental research is needed to understand better the transformations of drugs, and other molecules, and to imagine the best methodology in order to decrease or eliminate the undesirable metabolites.

\section{Is the Green Pill an Utopia?}

As the flow of drugs and metabolites to the environment (Fig. 5) can pollute the environment, some trials were carried out to transform pharmaceutical active ingredients into molecules having the same activity with human patient, but breaking down easily under the natural envi ronmental conditions, as glufosfamide, obtained by the modification of a known leading structure [24].

Glufosfamide (Fig. 6) is a glycoconjugate obtained by associating glucose with ifosfamide $[25,26]$. The rational is because the cancer cells have an increased affinity to glucose called "the Warburg effect". Glufosfamide has proven cytotoxic effects in preclinical and clinical trials, with many tumors. At the same time, its biodegradability is enhanced. It was proven that the biodegradability of this kind of compound depends on the stereochemistry of the glucoconjugate [27].

The computer aided design of new active molecules, in terms of discovery and development, showed its interest, to develop new drugs for various diseases, in particular for cancer therapies [28]. The use of this high technology could be a new way to develop drugs "benign by design", and better biodegradable pharmaceuticals. Anyhow, if this is an excellent target and model to follow, it will require many years to make all drug substances "benign by design", and the in silico screening for an early selection of drug candidates with favourable properties with regard to degradation is considered as still in its infancy [29].<smiles>O=P1(NCCCl)OCCCN1CCCl</smiles>

$6 a$

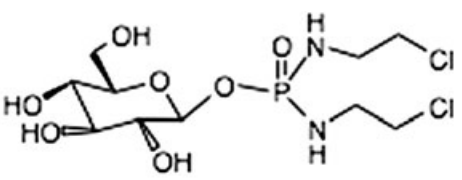

$6 \mathrm{~b}$
Fig. 6 Isofosfamide (a) and Glufosfamide (b) 


\section{Greener Drugs by Advanced Galenic?}

Galenics is a very traditonal science and art, and is con sidered in Europe as an invention by Galen [30], who developed the fist galenic form, a pill made of a mixture of gum and a drug. Nowadays, many dosage forms have been developed, considered as traditional dosage forms, such as a tablet, the most popular and used dosage form in phar macy because of its low cost and handiness for patients. Galenics shifted in the past decade from an empiric for mulation to an engineered approach of pharmaceutical technology. New galenics aims to deliver the right dose of active ingredient at the right time and the right place. It means to use advanced pharmaceutical technology, and to invent and to develop adapted intelligent Drug Delivery Systems. It can be noted that a pharmaceutical dosage form contains not only active ingredients, but also excipients. Many of them come from natural sources, as cellulose, starch, gelatin, lactose, ..., and are widely used after transformation and/or purification. One tendency is to develop more and more excipients coming from natural sources (pectin, trehalose, chitosan,...), due to their better sustainability. It will not be developed in this review, and the readers interested in this area are invited to consult the extensive literature dedicated to it [31 35].The develop ment of advanced galenics, including the use of futuristic high technology nanodrugs [36] is now exponential. For this reason, it is inconceivable to present an exhaustive panorama. Some emblematic examples of developments contributing to green drug are described hereafter.

One way of progress is to improve drug bioavailability by advanced galenics, decreasing the footprints of dosage forms and drugs in the environment. Many examples of improvements appeared in the literature, as for instance the enhancement of biovailability of poorly water soluble drugs, typically Class II drugs of the biopharmaceutics classifica tion system (BCS, [37]) showing high lipophilicity and high lattice energy [38] by the use of various technologies. One important challenge is to develop particle engineering for drug delivery, in order to integrate these particles in dosage forms. Particle engineering for pulmonary delivery has drawn much attention. For this purpose, the properties of particles [39] in terms of size distribution, shape, morphol ogy, flowability, surface energy, stability... must be well adapted to this application route.

Particle engineering strategies traditionally include top down and bottom up methodologies

Among the top down methodologies, one can notice the micronization [40] for instance using a jet milling. It allows to produce very fine particles and it has the advantage of being an industrial method. One drawback is that the granulometric particle size distribution is some times broad, and it is rather difficult to control the shape, morphology, surface properties and electrostatic charge of the particles, since the newly created surfaces are ther modynamically activated, which create some instabilities. Another risk is to decrease the crystallinity and enhance the surface and chemical degradation, and to decrease the flowability. Some processes were developed as for instance the co micronization of fenofibrate with various adjuvants as lactose monohydrate or microcrystalline cellulose, to improve the dissolution speed [41]. Drug micronization can be obtained by spray drying of a drug solution. But in this case, the particles are thermodynamically activated. The obtained amorphous particles show a tendency to recrys tallize, thus changing the dissolution speed and then the future bioavailability of these particles. Spray Freeze dry ing using liquid nitrogen was used to prepare hollow por ous microparticles of heat sensitive drugs [39].

Beside drug micronization, nanomization [42] by dry or wet process was carried out for solid active ingredients. When the size of particles decreases, the dissolution kinetics increases, and this allows to decrease the dose of active ingredients [43]. The use of supercritical solvents for fine particles design increased recently [44], and Bettini et al. reported that if some processes have been already scaled up to industrial manufacturing, the potential of this technology still remains largely unexplored. An inhalable insulin was developed, but an increased incidence of lung cancer among previous smokers was noticed after inhalable insulin treatment. Furthermore the treatment cost was much higher than the traditional form. Nevertheless it was found recently that inhalable insulin could present the advantage of attenuating pulmonary inflammation [45].

Bottom up strategies show some advantages, as for instance lower energy use than grinding, but on the other hand they call for solvent use. Among them, we can quote the microcrystallization of drugs. It has been developed to overcome milling induced disorders of crystalline pow ders. Another method was developed to stabilize inhalable proteins, to provide flowability, dispersibility and bio chemical and conformational stability of the proteins, using supercritical fluid technology [39].

If the use of spherical crystallization [46] and the quasi emulsion solvent diffusion (QESD, Fig. 7) method has been well known to improve the properties of active ingredients [47], an antisolvent process involving ionic liquids was used recently to prepare ultrafine rifampicyne particles [48].

\section{Tools for Advanced Galenics}

Many tools can be used to develop dosage forms, com bining top down and bottom up technologies: 
Fig. 7 Spherical crystallization by QESD method [47]

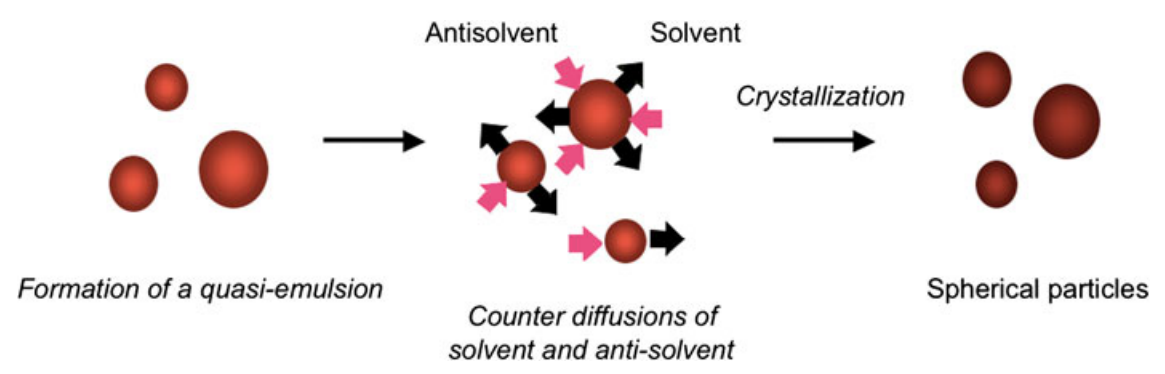

Counter diffusions of
solvent and anti-solvent
- amorphization of active ingredients by various methods among them the solvent method, the milling technology or the hot melt method [49]. The amorph form of drug is often more soluble than crystalline one. This way can be used to decrease the drug dose. The risk is to generate a crystallization inside the dosage form, and to loose a part of the drug activity during conservation. Some researchers proposed to stabilize amorph forms inside polymers for instance [50], and/or to produce solid dispersions [51, 52].

- use of a drug's more soluble polymorphic variety. In this case, the risk would be to create another crystalline form during the process or during conservation. Drug nanocrystals of indomethacine in the metastable form were produced using hydrophilic adjuvents as stabiliz ers [53].

- salts formation; the salts of active ingredients are generally much more soluble in water than the basic or the acidic form.

- co crystallization was developed rather recently and is a good tool as well to improve the bioavailability of drugs [54].

- encapsulation inside cyclodextrins: Hydrophobic drugs with low solubility can be encapsulated into hydro philic cyclodextrins, and then their apparent solubility increases during the time necessary for sufficient absorption $(26 \mathrm{~h})$ in the gastrointestinal tractus. Then the active ingredient can pass the gastro intestinal barrier and the drug is transferred to the blood (Fig. 8). This encapsulation allows to decrease the active ingredient dose in a drug, and its daily dose, as observed also in the case of liposome encapsulation [55]. Various processes were proposed for cyclodextrin encapsulation including comelting [56], kneading [57, 58], or use of supercritical $\mathrm{CO}_{2}$ [59]. This last possibility is very efficient, but expensive at the industrial scale.

Many combinations were developed from the above mentioned technologies, as to combine the use of cyclodex trins and nanoparticles [60], or to combine co crystallization and extrusion [61].

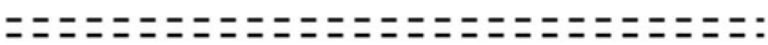

Gastro-intestinal system

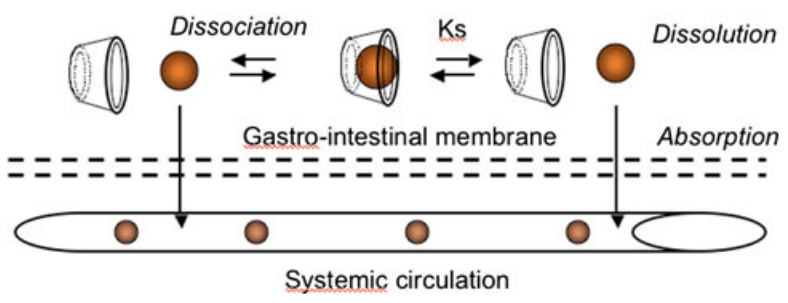

Fig. 8 Drug absorption after cyclodextrin encapsulation (adapted from [59])

Advanced Drug Delivery Systems (DDS)

If the first DDS were developed in order to increase the concentration of drug in the blood, the new DDS aim to maintain locally in the body precise drug concentrations. Another development is to use drug delivery technology for tissue engineering and regenerative medecine [62]. Many intelligent drug delivery systems were developed including photoresponsive polymersomes [63] (vesicles desintegrating upon U.V. irradiation), two layered dis solving microneedles for percutaneous delivery of pep tides/protein [64], etc. Some efforts were carried out to develop sustainable release [65, 66].

The development of advanced galenics is now expo nential. This is a good news for the patients. One limitation will be the cost of these technologies. Another is the safety of drug use.

\section{Less Footprints for Fine Chemicals and Biotech Active Pharmaceutical Ingredients (API)}

Concerning pharmaceutical fine chemicals and biotech active ingredient, increasing handling and use measures at the source is necessary in the long run. Due to the speci ficity, complexity, multistep character and purity targeted on these syntheses, the primary pharmaceutical production of API is considered as having one of the worst $\mathrm{E}$ factor 
among the chemical industry sector (25 $100 \mathrm{~kg}$ or more of waste by $\mathrm{kg}$ of API produced) [67]. If the bio industries involved in the production of drugs need very small amount of solvent, they need a deal of water for production and cleaning [68]. The big pharmaceutical companies worked a lot on their processes, to simplify and make them greener. Process R \& D must design the best synthetic routes for active ingredients.

\section{Small Molecules Syntheses}

To synthetize small molecules as API, the companies search how to decrease the energy and time used for uni tary operations, the amount of solvent... Some use microwaves to warm up the polar entities [69] for the scale up of organic reactions in a pharmaceutical Kilo lab. Other use ultrasonic conditions, since ultrasonic irradiation enhances chemical reactions and mass transfers via acoustic cavitation [70, 71] and many work on the pro cesses intensification, as reported by Buchholtz [72], introducing more continuous chemical reactions. As edicted by Sheldon [73] "the best solvent is no solvent", and some possibilities were proposed in order to use sol vent free syntheses in high energy vibrating ball mills [74, 75] (Fig. 9). Due to the co grinding stochastic character, the kinetics is sometimes slow. Nevertheless, this method is interesting, because the absence of solvent makes often the synthesis globally safer, faster, energy and cost effi cient. Due to high API complexity, and stereoisomeric needs, catalytic methodologies are often chosen, but as noticed by Federsel from Astra Zeneca [76], many cata lysts used today contain a heavy metal component, and this can induce a contamination of the product and of the wastes as well. For this reason, a catalytic process is rarely green, and many companies are in search of green catalysts [77].

\section{Enzymatic Methodologies}

Use of enzymatic methodologies is an interesting way, since an enzyme can be considered as a natural cata lyst, and the specificity of enzymes can be enhanced by

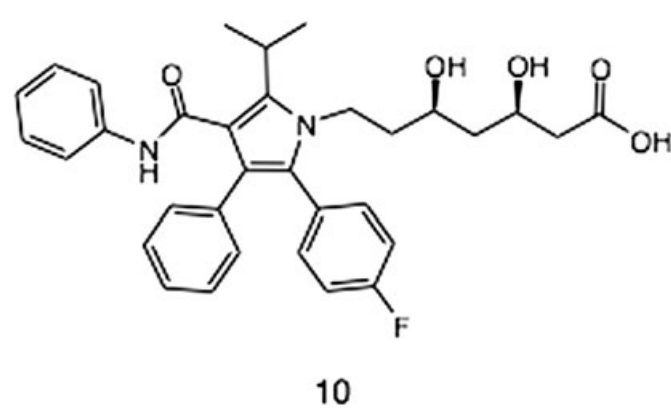

Fig. 10 Atorvastatin 10

mutations of the protein chains. Some companies devel opped the use of enzymes instead of microorganisms, as DSM to produce semi synthetic penicillins, decreasing drastically the use of solvents for the purification steps, and purer antibiotics were obtained by this way [78]. They reduced energy consumption by $66 \%$, and wastes by $90 \%$ compared to the traditional process. Another example is the synthesis of atorvastatin (10, Fig. 10), the active ingredient of Lipitor invented by Pfizer to treat hypercholesterolemia, one of the most sold drug in the world. The chemical synthesis of atorvastatin, uses traditionally cyanide and stoechiometric sodium borohydride (at $-70{ }^{\circ} \mathrm{C}$ ) to produce 200T/year of the key chiral building block ethyl $(R) 4$ cyano 3 hydroxybutyrate (Hydroxynitrile 11, Fig. 11). But the obtention of this intermediate needs a separation of the racemic to isolate the good isomer. Codexis developped a new "green by design" biocatalytic process using Halo hydrin deshalogenase customized enzyme (Fig. 11) [79]. Table 1 [80] shows the advantages of the bio synthesis in terms of energy, yield, concentration... This biosynthesis was developped at a multi tons scale.

Similarly, Merck and Codexis improved drastically sitagliptin (antihyperglycemic drug used against diabete) synthesis, using a customized enzyme [81].

In a general point of view, big pharmas think green and to search new alternatives for primary production pro cesses. Two main ways of progress are developed: syn thesis of small molecules by direct routes, using less solvents, and if possible water or no solvent. When the complexity is increased, or in case of stereospecificity, use

Fig. 9 Dibenzophenazines (a, b) and dibenzopyrido quinoxaline (c) solvent free synthesis $[74,75,77]$<smiles>[H][Z]1ccc(N)c(N)c1</smiles><smiles></smiles>

9a. $R=H, \quad X=C$ 9b. $R=M e, X=C$ 9c. $\mathrm{R}=\mathrm{H}, \quad X=\mathrm{N}$ 

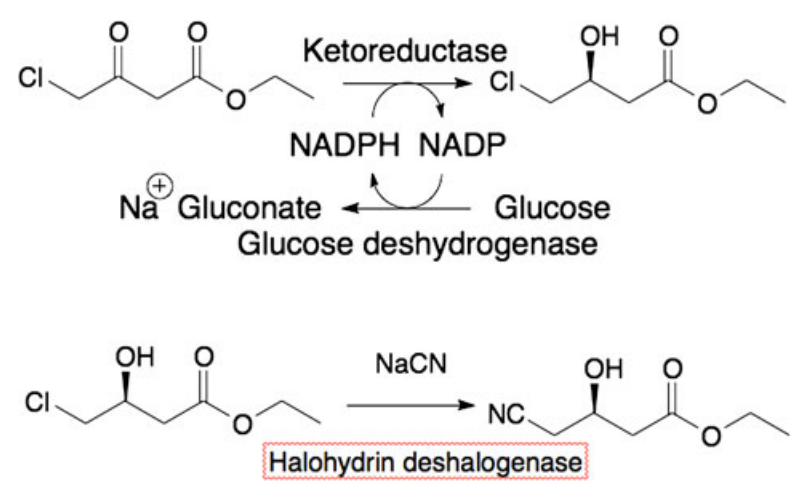

Hydroxynitrile

11

Fig. 11 Synthesis of Atorvastatin key intermediate Hydroxynitrile 11 (adapted from [79])

Table 1 Comparison of the biocalytic and chemical processes for the production of Hydroxynitrile [80]

\begin{tabular}{lll}
\hline Parameter & $\begin{array}{l}\text { Enzymatic } \\
\text { process }\end{array}$ & $\begin{array}{l}\text { Chemical } \\
\text { process }\end{array}$ \\
\hline $\begin{array}{l}\text { Crude substrate load } \\
\text { Substrate/catalyst (wt/wt) }\end{array}$ & $\begin{array}{l}0.3 \mathrm{~kg} / \mathrm{L} \\
\text { Approximately } \\
100: 1\end{array}$ & $0.1 \mathrm{~kg} / \mathrm{L}$ \\
& 99.3 & \\
Conversion (\%) & 99.99 & $\begin{array}{l}\text { Not } \\
\text { provided }\end{array}$ \\
$\begin{array}{l}\text { Diastereomeric excess } \\
(\%)\end{array}$ & 94 \\
$\begin{array}{l}\text { Cryogenic reaction } \\
\text { conditions required }\end{array}$ & No & Yes \\
\begin{tabular}{l} 
Solvent use \\
\hline
\end{tabular} & $3.2 \mathrm{~L} / \mathrm{kg}$ & $27.5 \mathrm{~L} / \mathrm{kg}$ \\
\hline
\end{tabular}

of catalysts or biotech ways are explored as well. In this case, isolation and recycling steps must be important key points of the process.

\section{Pharmaceutical Forms Greener Manufacturing}

Beginning of 2000, the Food \& Drug Administration (FDA) inspectors noticed that the actual yields in the drug formulation (secondary production) facilities were lower than expectation in the marketing authorization applica tions, and that the production time was often much longer. Furthermore, they noticed that a lot of products which were not matching the quality standards had to be destroyed. The result was the implementation of quality by design (QbD) for pharmaceutical products research, development and production. This concept is linked to the process analytical technology (PAT) one, allowing the continuous monitoring of pharmaceutical processes, in order to ensure products final quality [82]. PAT is very well adapted to continuous processes and it is developing progressively in the industry,

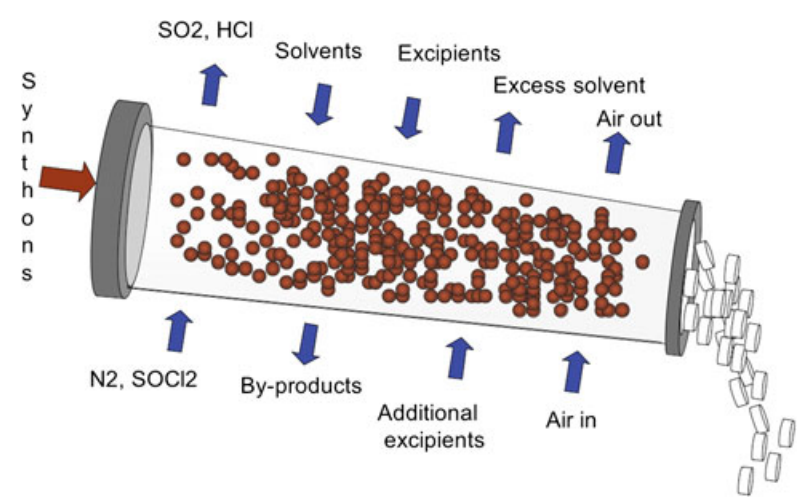

Fig. 12 Symbolic pharmaceutical continuous process (after [84])

with various applications [83]. Novartis and the MIT develop a joint program "Blue sky vision" to transform batch oriented pharma production to a fully continuous approach [84] integrating QbD, and starting from chemical synthesis through final pharmaceutical dosage form (Fig. 12), promising impressive advantages in terms of total capital and operating costs.

If the idea of producing tablets by continuous process was launched some years ago [85], GSK, GEA and Sie mens developed a new system for tablet continuous man ufacturing [86]. Concerning the specific continuous drying and tabletting process, the savings aimed is $65 \%$ lower building volume, $60 \%$ lower capital cost, $85 \%$ less waste, $60 \%$ less manpower, and less solvent. Some research groups in the world work on the questions raised by con tinuous blending of powder mixtures with pharmaceutical constraints [87].

If the development of continuous processes needs research and development investments, and investments in new machines at the beginning, it can generate profits in the long term, by increasing the yields of pharmaceutical forms, and helping to make the processes greener than before, then generating other advantages to the company. Recently, Pfizer developed the co design by modeling between R \& D and manufacturing [88], allowing the members of the team to examine each step of possible route, for commercial nomination. Use of continuous pro cesses is generally a good way to cut costs, and the tech nology is emerging in the pharmaceutical industry manufacturing [89]. At the same time, at the research level, new cost effective green processes are explored, which can be implemented in future more or less continuous manu facturing processes. These can be for instance direct compression [90], fast melt granulation [91], extrusion/ spheronization in the presence of water as solvent with various grid geometries [92, 93] (Fig. 13), coating pro cesses using water instead of organic solvents [83], dry coating [94 97] or other green processes. 


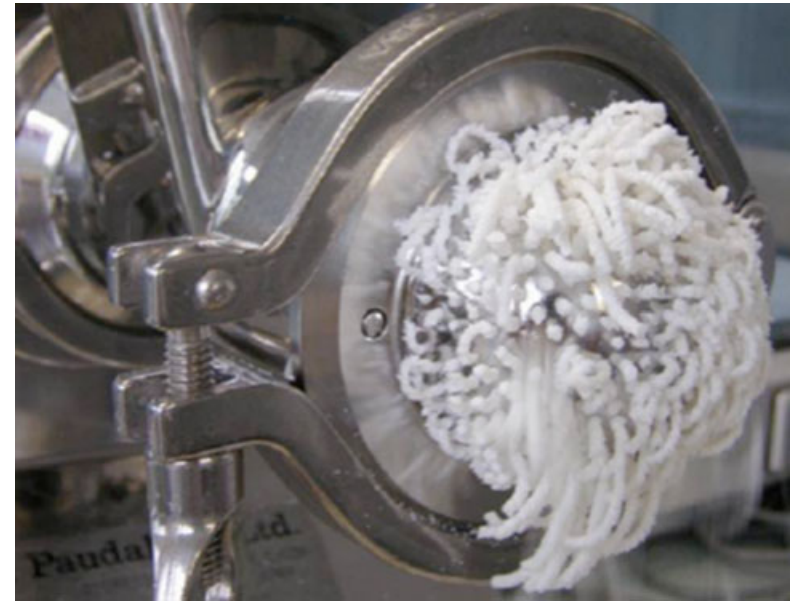

Fig. 13 Pharmaceutical extrusion using a dome geometry grid [92, 93]

\section{Good Use Practices}

In order to preserve a safe environment, it seems obvious that our societies must evolve in the direction of dimin ishing drugs dissemination in the environment. A similar way is aimed for agriculture (intrants and phytosanitary products), and of course in a general point of view in the use of all kind of chemical products.

For the pharmaceutical drugs, a safe dispensation of the exact dose of drug needed by the patient in the case of prescriptions must be organized. In the case of self medi cation as well, the behaviour of the patient is important, avoiding overmedication. When drugs remain in the medecine chest, and of course when the expiration date is over, the patients must go to retail pharmacies, to give back the remaining drugs. A system exists in many european countries to recover and destroy them by incineration. Since the recycling by humanitary associations is not longer in use (mainly due to quality defects), this system is the best to avoid the dissemination of drugs in the nature. The FDA recommends a few medicines to be flushed down the sink or toilet to help prevent danger to people and pets in the home [98]. This is only in some cases as aspirin, very rapidly destroyed in water and destroyed at $99.9 \%$ in water treatment plants. But this choice is difficult for the people not well informed of the complexities and varieties of drug molecules. Some researchers published recently a life cycle comparison of environmental emissions from three dis posal options for unused pharmaceuticals [99], and rec ommended as a result the trash disposal of unused pharmaceuticals. But it is without taking into consideration the fact that after a while, the molecules can diffuse and pollute the environment. Then the incineration with energy recovery is at the present time the best way to destroy the medecines and their packaging, excepted in the case of drugs or organic products needing a special treatment $[15,16]$. It is of course regrettable not to recycle the drug and provide them to affected populations, but the good solution for this was not found until now, despite some interesting proposals to improve the liability [100].

For this, the recovery of unused drugs by patients, a social education is necessary for the proper disposal of unused and expired medications in all countries [9].

A particular attention should be paid to hospitals and care institutions, to avoid toxic effluent discharge, due to relative high concentration of drugs in the effluents. We also must consider the fact that a reprocessing of drugs is possible in the industrial processes, if it has been antici pated in the marketing authorization [101]. Following recovery of the active ingredient and recystallization, a new expiry date can be attributed, to avoid a waste of drug.

If the focus was made on the drugs in this paper, more generally, many other molecules (PCB, phtalates, bisphe nol A, herbicides, and traces of more simple molecules as flame retardants, glycol ethers...), could have an impact on environment. Then, even if some adapted methods have been developed to eliminate these molecules from the environment [15], the best choice is to decrease the dos ages applied, and to avoid the dissemination of the leftover products in the environment.

The notion of Ecopharmacovigilance is developing, to evaluate and to control the risk of dissemination of phar maceutical drugs in the environment, and decrease the emission level. This should be applied to all kinds of molecules potentially harmful for the environment, alone or in mixtures.

\section{Conclusions}

For the last decade the pharmaceutical industry moved towards making greener products and processes. This goal will be attained by using more eco design in active ingre dients and drugs conception, as well as the processes at all stages of $\mathrm{R} \& \mathrm{D}$ and production. Among the various pos sibilities, it is possible to quote:

- development of processes using only water, or solvent free processes

- use of catalysts, and if possible green catalysts

- development of continuous processes

- development and implementation of PAT for in process control and to increase pharmaceutical operations yield

- development of an advanced galenic, including DDS, to ensure drug delivery of the right dose, at the right time, and at the right place. 
- lean and project management at all steps of develop ment and production

Research in new emerging processes requires multi disciplinary teams to work together, and of course some investments in R \& D. The cost of these technologies must be well considered but they will help to match the objective of sustainability. And there is no longer doubt that the return to investment will be efficient, for the companies and their development as well as the health economy, and for our planet environment. If the phar maceutical drugs "benign by design" could be an inter esting target for the future, the processes generated by eco design for primary and secondary processing must be both ecologically and economically efficient, to save costs and create the future of pharmaceutical companies, of health organizations systems, and of our planet. A social education will contribute to avoid the dissemination of potential harmful products in the environment, and to recover unused drugs by the patients.

Acknowledgments Some case studies cited in this article were made by former and present coworkers and Ph'D students in our research center RAPSODEE (Ecole des Mines d'Albi CNRS Uni versité de Toulouse France) and/or Spin Center (Ecole des Mines de St Etienne, France) and/or Paris South XI University France, whose names appear only in the reference list. The author expresses his sincere appreciation for their tremendous efforts invested in their research works. Financial supports are also appreciated, among others those from the Ministry of Economy, Finances and Industry, from the Centre National de la Recherche Scientifique (CNRS) and from the Agence Nationale pour la Recherche (ANR).

\section{References}

1. Gurib Fakim, A.: Medicinal plants: traditions of yesterday and drugs of tomorrow. Mol. Asp. Med. 27, 193 (2006)

2. Morphine: http://fr.wikipedia.org/wiki/Morphine. Accessed 13 Oct 2011

3. Potier, P.: A la recherche et à la découverte de nouveaux médicaments. In: Baron M., Dodds J. (eds.) Albi Int. Rencontres in Pharm. Engin., pp. 13 24. ISBN 139782951159150 , Ecole des Mines d'Albi Carmaux, Albi (2004)

4. Fleming, A.: On the antibacterial action of cultures of penicil lium, with special reference to their use in the isolation of B. influenzae. Brit. J. Exp. Pathol. 10, 226236 (1929)

5. Imhoff, J.F., Labes, A., Wiese, J.: Bio mining the microbial treasures of the ocean: new natural products. Biotechnol. Adv. 29, 468482 (2011)

6. Deichmann, W.B., Henschler, D., Holmstedt, B., Keil, G.: What is there that is not poison? A study of the third defense by paracelsus. Arch. Toxicol. 58, 2072013 (1986)

7. The University of Nottingham.: The liver and drug metabolism. http://www.nottingham.ac.uk/nmp/sonet/rlos/bioproc/liverdrug/ 2.html. Accessed 8 June 2012

8. Vree, T.B., Van den Biggelaar Martea, M., Verwey Van Wis sen, C.P.W.G.M., Vree, M.L., Guelen, P.J.M.: The pharmaco kinetics of naproxen, its metabolite $\mathrm{O}$ desmethylnaproxen, and their acylglucuronides in humanEffect of cimetidine. Br. J. Clin. Pharmacol. 35, 467472 (1993)

9. Apoteket AB.: Pharmaceuticals, environment and Health. http:// www.janusinfo.se/Global/Miljo och lakemedel/lakemed miljo eng2007.pdf (2006). Accessed 13 Oct 2011

10. Houeto, P., Carton, A., Guerbet, M., Mauclaire, A. C., Gatignol, C., Lechat, P., Masset, D.: Assessment of the health risks related to the presence of drug residues in water for human consump tion: application to carbamazepine. Regul Toxicol Pharmacol 62, 4148 (2012)

11. International ChemSec: NGOs express concern with European Commission's position on chemical mixtures. http://Users/bar on/Desktop/Review\%20Waste\%20Biomass\%20Valor/phytosani tary,\%20insecticides, \%20herbicides/www.sinlist.org.webarchive. Accessed 6 June 2012

12. Xu, Y., Luo, F., Pal, A., Gin, K.Y. H., Reinhard, M.: Occurrence of emerging organic contaminants in a tropical urban catchment in Singapore. Chemosphere 83, 963969 (2011)

13. Dang, Z., Cheng, Y., Chen, H., Cui, Y., Yin, H., Trass, T. Montforts, M., Vermeire, T.: Evaluation of the Daphnia magna reproduction test for detecting endocrine disruptors. Chemo sphere 88, 514523 (2012)

14. Brozinski, J. M., Lahti, M., Oikari, A., Kronberg, L.: Detection of naproxen and its metabolites in fish bile following intra peritoneal and aqueous exposure. Environ. Sci. Pollut. Res. 18, 811818 (2011)

15. Zhang, Q.W., Matsumoto, H., Saito, F., Baron, M.: Debromin ation of hexabromobenzene by its co grinding with $\mathrm{CaO}$. Che mosphere 48(8), 787793 (2002)

16. Zhang, Q.W., Lu, J.F., Saito, F., Baron, M.: Mechanochemical solid phase reaction between polyvinylidene fluoride and sodium hydroxyde. J. Appl. Polym. Sci. 81(9), 22492252 (2001)

17. Ramaroson, J., Dirion, J.L., Nzihou, A., Sharrock, P., Depelse naire, G.: Calcination of dredged sediments: investigation of the behaviour of heavy metals and the organic compounds. High Temp. Mat. Process. 27(5), 327336 (2008)

18. Lafhaj, Z., Duan, Z., Bel Hadj Ali, I., Depelsenaire, G.: Valo rization of treated river sediments in self compacting materials. Waste Biomass Valoris. 3(2), 239247 (2012)

19. Singh, J.S., Abhilash, P.C., Singh, H.B., Singh, R.P., Singh, D.P.: Genetically engineered bacteria: an emerging tool for environmental remediation and future research perspectives. Gene 480(1 2), 19 (2011)

20. Massot, A., Estève, K., Noilet, P., Méoule, C., Poupot, C., Mietton Peuchot, M.: Biodegradation of phytosanitary products in biological wastewater treatment. Water Res. 46, 17851792 (2012)

21. Kümmerer, K.: Pharmaceuticals in the environment. Annu. Rev. Environ. Ressour. 35, 5775 (2010)

22. Trautweil, C., Kümmerer, K.: Degradation of the tricyclic antipsychotic drug chlorpromazine under environmental condi tions, identification of its main aquatic biotic and abiotic transformation products by LS MS ${ }^{\mathrm{n}}$ and their effects on envi ronmental bacteria. J. Chromatogr. B 889-890, 2438 (2012)

23. McCormick, J.M., Van Es, T., Cooper, K.R., White, L.A., Häggblom, M.M.: Microbially mediated O methylation of bi sphenol a results in metabolites with increased toxicity to the developing zebrafish (Danio rerio) embryo. Environ. Sci. Technol. 45(15), 65676574 (2011)

24. Kümmerer, K.: The presence of pharmaceuticals in the envi ronment due to human use present knowledge and future challenges. J. Environ. Manag. 90(8), 23542366 (2009)

25. Pohl, J., Bertram, B., Nowrousian, M.R., Stüben, J., Wiessler, M.: D 19575 a sugar linked isophosphoramide mustard derivative exploiting transmembrane glucose transport. Cancer Chemother. Pharmacol. 35, 364370 (1995) 
26. Mazur, L., Opido Chanek, M., Stojak, M.: Isofosfamide as a new oxazaphosphorine anticancer agent. Anticancer Drugs 22(6), 488493 (2011)

27. Kümmerer, K., Al Ahmad, A., Betram, B., Wiessler, M.: Bio degradability of antineoplastic compounds in screening tests: influence of glucosidation and stereochemistry. Chemosphere 40, 767773 (2000)

28. Zhang, S.: Computer aided drug discovery and development. Methods Mol. Biol. 716, 2338 (2011)

29. Steger Hartmann, T., Länge, R., Heuck, K.: Incorporation of in silico biodegradability screening in early drug development a feasible approach? Environ. Sci. Pollut. Res. 18, 610619 (2011)

30. Daremberg C.: Euvres anatomiques, physiologiques et médi cales de Galien, T.1, J.B. Baillère Ed., Paris (1854)

31. Sriamornsak, P.: Application of pectin in oral drug delivery. Expert Opin. Drug Deliv. 8(8), 10091023 (2011)

32. Avachat, A.M., Dash, R.R., Shrotriya, S.N.: Recent investiga tions of plant based natural gums, mucilages and resins in novel drug delivery systems. Indian J. Pharm. Educ. Res. 45(1), 8699 (2011)

33. Hamman, J.H.: Chitosan based polyelectrolyte complexes as potential carrier materials in drug delivery systems. Mar. Drugs 8(4), 13051322 (2010)

34. Faivre, V., Rosilio, V.: Interest of glycolipids in drug delivery: from physicochemical properties to drug targeting. Exp. Opin. Drug Deliv. 7(9), 10311048 (2010)

35. Rasala, T.M., Kale, V.V., Lohiya, G.K., Moharir, K.S., Ittadwar, A.M., Awari, J.G.: Chemistry and pharmaceutical applications of excipients derived from tamarind. Asian J. Chem. 23(4), 14211423 (2011)

36. Chan, H. K.: Nanodrug particles and nanoformulations for drug delivery. Adv. Drug Deliv. Rev. 63, 405 (2011)

37. Amidon, G.L., Lennernas, H., Shah, V.P., Crison, J.R.: A the oretical basis for a biopharmaceutic drug classification the correlation of in vitro drug product dissolution and in vivo bioavailability. Pharm. Res. 12(3), 413420 (1995)

38. Rogers, T.L., Johnston, K.P., Williams III, R.O.: Solution based particle formation of pharmaceutical powders by supercritical or compressed fluid $\mathrm{CO}_{2}$ and cryogenic spray freezing technolo gies. Drug Dev. Ind. Pharm. 27(10), 10031015 (2001)

39. Ragab, D.M., Rohani, S.: Particle engineering strategies via crystallisation for pulmonary drug delivery. Org. Process Dev. 13, 12151223 (2009)

40. Han, X., Ghoroi, C., To, D., Chen, Y., Davé, R.: Simultaneous micronization and surface modification for improvement of flow and dissolution of drug particles. Int. J. Pharm. 415(1 2), 185195 (2011)

41. Shermann B.C.: Pharmaceutical compositions comprising co micronized fenofibrate. US Patent 6555135, (2000)

42. Merisko Liversidge, E., Liversidge, G.: Nanosizing for oral and parenteral drug delivery: a perspective on formulating poorly water soluble compounds using wet media milling technology. Adv. Drug Deliv. Rev. 63(6), 427440 (2011)

43. Zhang, L.L., Chai, G.H., Zeng, X.P., He, H.B., Xu, H., Tang, X.: Preparation of fenofibrate immediate release tablets involving wet grinding for improved bioavailability. Drug Dev. Ind. Pharm. 36(9), 10541063 (2010)

44. Pasquali, I., Bettini, R., Giordano, F.: Solid state chemistry and particle engineering with supercritical fluids in pharmaceutics. Eur. J. Pharm. Sci. 27, 299310 (2006)

45. Shapiro, H., Kagan, I., Shalita Chesner, M., Singer, J., Singer, P.: Inhaled aerosolized insulin: a « Topical » anti inflammatory treatment for acute lung injury and respiratory distress syn drome? Inflammation 33(5), 315319 (2010)
46. Kawashima, Y., Capes, C.E.: An experimental study of the kinetics of spherical agglomeration in a stirred vessel. Powder Technol. 10, 8592 (1974)

47. Nocent, M., Bertocchi, L., Espitalier, F., Baron, M., Couarraze, G.: Definition of a solvent system for spherical crystallization of salbutamol. J. Pharm. Sci. 13, 12151223 (2009)

48. Viçosa, A., Letourneau, J.J., Espitalier, F., Ré, M I.: J. Cryst. Growth. doi:10.1016/j.jcrysgro.2011.09.012 (2011)

49. Jojart Laczkovich, O.J., Szabo Revesz, P.: Amorphization of a crystalline active ingredient and thermoanalytical measurements on this glassy form. J. Therm. Anal. Calorim. 102, 243247 (2010)

50. Mikhailenko, M.A., Shakhtshneider, T.P., Debushchak, V.A., Kuznetsova, S.A., Skvortsova, G.P., Boldyrev, V.V.: Influence of mechanical treatment on the properties of betulin, betulin diacetate, and their mixture with water soluble polymers. Chem. Nat. Compd. 47(2), 229233 (2011)

51. Kakran, M., Sahoo, N.G., Li, L.: Dissolution enhancement of quercetin through nanofabrication, complexation and solid dis persion. Colloids Surf. B. Biointerfaces 88(1), 121130 (2011)

52. Babar, I., Asgar, A., Javed, A., Sanjula, B., Sonal, G., Schweta, D., Shadab, M., Jasjeet, K.S.: Recent advances and patents in solid dispersion technology. Recent Pat Drug Deliv Formul 5(3), 244264 (2011)

53. Makhlof, A., Miazaki, Y., Tozuka, Y., Takeuchi, H.: Cyclo dextrin as stabilizers for the preparation of drug nanocrystals by the emulsion solvent diffusion method. Int. J. Pharm. 357(1 2), 280285 (2008)

54. McNamara, D.P., Childs, S.I., Giordano, J., Iarriccio, A., Cas sidy, J., Shet, M.S., et al.: Use of a glutaric acid cocrystal to improve oral bioavailability of a low solubility API. Pharm. Res. 23, 18881897 (2006)

55. Elibogen, M.H., Olsen, K.M., Gentry Nielsen, M.J., Preheim, L.C.: Efficacy of liposome encapsulated ciprofloxacin compared with ciprofloxacin and ceftriaxone in a rat model of pneumoccoccal pneumonia. J. Antimicrob. Chemother. 51(1), 8391 (2003)

56. Miro, A., Quaglia, F., Giannini, L., Capello, B., La Rontonda, M.I.: Drug/cyclodextrin solid systems in the design of hydro philic matrices: a strategy to modulate drug delivery rate. Curr. Drug Deliv. 3(4), 373378 (2006)

57. Gil, A., Chamayou, A., Leverd, E., Bougaret, J., Baron, M., Couarraze, G.: Evolution of the interaction of a new chemical entity, eflucimibe, with gamma cyclodextrin during kneading process. Eur. J. Pharm. Sci. 23, 123129 (2004)

58. Hutin, S., Avan, J.L., Paillard, B., Baron, M., Couarraze, G., Bougaret, J.: Analysis of a kneading process to evaluate drug substance cyclodextrin complexation. Pharm. Technol. 28, 112124 (2004)

59. Fages, J., Rodier, E., Chamayou, A., Baron, M.: Comparative study of two processes to improve the bioavailability of an active pharmaceutical ingredient: kneading and supercritical technology. KONA 25, 217229 (2007)

60. Agueros, M., Zabaleta, V., Espuelas, S., Campanero, M.A., Ir ache, J.M.: Increased oral bioavailability of paclitaxel by its encapsulation through complex formation with cyclodextrins in poly(anhydride)nanoparticles. J. Controlled Release 145(1), 28 (2010)

61. Dhumal, R.S., Kelly, A.L., York, P., Coates, P.D., Paradkar, A. Cocrystalization and simultaneous agglomeration using hot melt extrusion. Pharm. Res. 27, 27252733 (2010)

62. Rosado Balmayor, E., Sepulveda Azevedo, H., Reis, R.L.: Controlled delivery systems: from pharmaceuticals to cells and genes. Pharm. Res. 28, 12411258 (2011)

63. Cabane, E., Malinova, V., Menon, S., Palivan, C.G., Meier, W. Photoresponsive polymersomes as smart, triggerable nanocarri ers. Soft Matter 7, 91679176 (2011) 
64. Fukushima, K., Ise, A., Morita, H., Hasegawa, R., Ito, Y., Sugioka, N., Takada, K.: Two layered dissolving microneedles for percutaneous delivery of peptide/protein drugs in rats. Pharm. Res. 28(1), 721 (2011)

65. Lee, D.H., Kang, S.G., Jeong, S., Yoon, C.J., Choi, J.A., Byun, J.N., Park, J.H., Lee, K.B.: Local delivery system of immune modulating drug for unresectable adenocarcinoma: in vitro experimental study and in vivo animal study. Cardiovasc. Interv. Radiol. 29(5), 832837 (2006)

66. Aburai, K., Yagi, N., Yokoyama, Y., Okuno, H., Sakai, K., Sakai, H., Sakamoto, K., Abe, M.: Preparation of liposomes modified with lipopeptides using a supercritical carbon dioxyde reverse phase evaporation method. J. Oleo Sci. 60(5), 209215 (2011)

67. Cue, B.W., Berridge, J., Manley, J.B.: PAT \& green chemistry: the intersection of benign by design and quality by design. Pharm. Engin. 29, 820 (2009)

68. Ho, S.V., McLaughlin, J.M., Cue, B.W., Dunn, P.J.: Environ mental considerations in biologics manufacturing. Green Chem. 12, 755766 (2010)

69. Lehmann, H., La Vecchia, L.: Scale up of organic reactions in a pharmaceutical Kilo lab using a commercial microwave reactor. Org. Process Res. Dev. 14, 650656 (2010)

70. Luche, J.L.: Synthetic Organic Chemistry. Plenum Press, New York (1998)

71. Louisnard, O.: A simple model of ultrasound propagation in a cavitating liquid. Part II: primary Bjerknes force and bubble structures. Ultrason. Sonochem. 19(1), 6676 (2012)

72. Buchholtz, S.: Future manufacturing approaches in the chemical and pharmaceutical industry. Chem. Eng. Process. 49, 993995 (2010)

73. Sheldon, R.A.: Green solvents for sustainable organic synthesis: state of the art. Green Chem. 7(5), 267278 (2005)

74. Carlier, L., Baron, M., Chamayou, A., Couarraze, G.: Use of co grinding as a solvent free state method to synthesize dibenzo phenazines. Tetrahedron Lett. 52, 46864689 (2011)

75. Carlier L., Baron M., Chamayou A., Couarraze G.: Greener pharmacy using solvent free synthesis: investigation of the mechanism in the case of dibenzophenazines. Powder Technol. doi:10.1016/j.powtec.2012.07.009 (2012)

76. Federsel, H. J.: In search of sustainability: process R\&D in light of current pharmaceutical industry challenges. Drug Discov. Today 11(21/22), 966974 (2006)

77. Baron, M., Chamayou, A., Carlier, L., Couarraze, G.: Dib enzophenazines synthesis by a smart green process. In: Pro ceedings of the 2nd International Conference on Environmental Pollution and Remediation. Montreal, Quebec, Canada, 2830 August 2012, paper no 105, 14 (in press)

78. De Braal, H.: Sustainability in green pharmaceutical production. Pharm. Technol. Eur. 21, 1, (2009), http://pharmtech.findphar ma.com/pharmtech/article/articleDetail.jsp?id=574860. Acces sed 14 Oct 2011

79. Ma, S.K., Gruber, J., Davis, C., Newman, L., Gray, D., Wang, A., Grate, G., Huisman, G.W., Sheldon, R.A.: A green by design biocatalytic process for atorvastatin intermediate. Green Chem. 12, 8186 (2010)

80. Rozzell, D., Codexis Inc.: Greener chemical processes from biocatalysis. http://www.codexis.com/pdf/Pharmachem 1008.pdf. Accessed 20 Oct 2011

81. Savile, C.K., Janey, J.M., Mundorff, E.C., Moore, J.C., Tam, S., Jarvis, W.R., Colbeck, J.C., Krebber, A., Fleitz, F.J., Brands, J., Devine, P.N., Huisman, G.W., Hugues, G.J.: Biocatalytic asy metric synthesis of chiral amines from ketones applied to si tagliptin manufacture. Science 329(5989), 305309 (2010)

82. FDA, Process Analytical Technology (PAT) Initiative http:// www.fda.gov/AboutFDA/CentersOffices/CDER/ucm088828.htm. Accessed 14 Oct 2011
83. Gendre, C., Genty, M., Boiret, M., Julien, M., Meunier, L., Lecoq, O., Baron, M., Chaminade, P., Pean, J. M.: Development of a Process Analytical Technology (PAT) for in line monitor ing of film thickness and mass of coating materials during a pan coating operation. Eur. J. Pharm. Sci. 43, 244250 (2011)

84. Trout, B., Bisson, W.: Continuous manufacturing of small molecule pharmaceuticals. The Ultra Lean Way of Manufac turing. http://ilp www.mit.edu/images/conferencemedia/trout. pdf. Accessed 14 Oct 2011

85. Klimesch, R., Mrosek, W., Bleckmann, G., Farwerk, K P., Sanner, A., Schlemmer, L.: Process for the preparation of pharmaceutical tablets. EP 0358107 to BASF (1990)

86. Ivo Backx.: Changing the clock speed. http://Users/baron/ Desktop/GSK\%20and\%20Siemens $\% 20$ continuous $\% 20$ tablet $\%$ 20manufacture.html. Accessed 10 Oct 2011

87. Berthiaux, H., Marikh, K., Gatumel, C.: Continuous mixing of powder mixtures with pharmaceutical constraints. Chem. Eng. Process. 47(12), 23152322 (2008)

88. Cordi, E.M., Schofield, R.: Leveraging green metrics for route selection and process optimization. http://www.pharmamanu facturing.com/articles/2011/053.html. Accessed 14 Oct 2011

89. Schaber, S.D., Gerogiorgis, D.I., Ramachandran, R., Evans, J.M.B., Barton, P.I., Trout, B.L.: Economic analysis of inte grated continuous and batch pharmaceutical manufacturing: a case study. Ind. Eng. Chem. Res. 50(17), 1008310092 (2011)

90. Mirani, A.G., Patankar, S.P., Borole, V.S., Pawar, A.S., Kadam, V.J.: Curr. Drug Deliv. 8(4), 426435 (2011)

91. Tayel, S.A., Soliman, I.I., Louis, D.: Formulation of ketotifen fumarate fast melt granulation sublingal tablet. AAPS Pharm scitech 11(2), 679685 (2010)

92. Desiré, A., Paillard, B., Bougaret, J., Baron, M., Couarraze, G.: Comparison between three extrusion systems on the properties of pellets prepared by extrusion spheronisation $\mathrm{I}$ : influence of water content and extrusion speed. Pharm. Technol. North Am. 35(1), 5665 (2011)

93. Desiré, A., Paillard, B., Bougaret, J., Baron, M., Couarraze, G.: A comparison of three extrusion systems Part II: influence of formulation and spheronization conditions on pellet properties. Pharm. Technol. North Am. 35(6), 5661 (2011)

94. Ouabbas, Y., Dodds, J., Chamayou, A., Galet, L., Baron, M.: Particle particle coating in a cyclomix impact mixer. Powder Technol. 189, 245252 (2009)

95. Ouabbas, Y., Chamayou, A., Galet, L., Baron, M., Thomas, G., Grosseau, P., Guilhot, B.: Surface modification of silica particles by dry coating: characterization and powder ageing. Powder Technol. 190(1 2), 200209 (2009)

96. Ouabbas, Y., Thomas, G., Grosseau, P., Guilhot, B., Baron, M., Chamayou, A., Galet, L.: Surface analysis of silicagel particles after mechanical coating with magnesium stearate materials. Appl. Surf. Sci. 255(17), 75007507 (2009)

97. Gera, M., Sahara, V.A., Kataria, M., Kukkar, V.: Mechanical methods for dry particle coating processes and their applications in drug delivery and development. Recent Pat Drug Deliv For mul 4(1), 5881 (2010)

98. FDA, Disposal of unused medecines: What you should know: http://Users/baron/Desktop/Review\%20Waste\%20Biomass\%20 Valor/recyclage\%20medicaments/Safe\%20Disposal\%20of\%20 Medicines $\% 20 \% 3 \mathrm{E} \% 20$ Disposal\%20of\%20Unused $\% 20 \mathrm{Medici}$ nes:\%20What $\% 20$ You $\% 20$ Should $\% 20$ Know.webarchive. Acces sed 8 June 2012

99. Cook, S.M., VanDuinen, B.J., Love, N.G., Skerlos, S.J.: Life cycle comparison of environmental emissions from three dis posal options for unused pharmaceuticals. Environ. Sci. Tech nol. 46(10), 55355541 (2012)

100. Pomerantz, J.M.: Recycling expensive medication: why not? Med. Gen. Med. 6, 24 (2004) 
101. FDA, Guidelines for submitting supporting documentation in drug applications for the manufacture of drug products. http:// Users/baron/Desktop/Review\%20Waste\%20Biomass\%20Valor/ recyclage \%20medicaments/Guidances\%20(Drugs)\%20\%3E\%2
0GUIDELINE\%20FOR\%20SUBMITTING\%20SUPPORTING \%20DOCUMENTATION\%20IN\%20DRUG\%20APPLICATIO NS\%20FOR\%20THE\%20M.webarchive. Accessed 8 June 2012 